\title{
A Diagnosis of Brazilian Shipbuilding Industry on the Basis of Methodology for an Analysis of Sectorial Systems of Innovation
}

\author{
Fernando Oliveira de Araujo', Paulo Roberto Tavares Dalcol²,Waldimir Pirró e Longo 3
}

\begin{abstract}
A recent resumption of Brazilian shipbuilding industry, driven by the purchasing power of the state, has presented controversial opinions concerning its effective contribution to, in the first instance, the innovation and competitiveness in the sector and secondly, for Brazilian development. The present study, conducted between November 2009 and May 20II, analyses the said industry from a methodology based on an approach of system sectors of innovation, seeking to highlight the existence and intensity of relationships between the main organizations and institutions, which are members of the industry, in addition to verifying the individual contributions of each of the stakeholders to the industrial competitiveness. As a result of the study, an accurate diagnosis is presented concerning the main aspects to be prioritized through the Brazilian shipbuilding industry, in addition to reviews of proposals of scientific and industrial policies directed towards the said industry, specifically as regards the granting of public funds for research and development demands be revised, as should be aligned to the real needs of the country and the productive sector.
\end{abstract}

Keywords: Brazilian shipbuilding industry; industrial organization; innovation; sectoral systems of innovation; scientific and industrial policies.

\footnotetext{
'Associate Professor. Production Engineering Department CEFET/RJ - Federal Centre for Technological Education of Rio de Janeiro Nova Iguaçu, Rio de Janeiro - Brazil.Tel: +55 21 8887-9805. Email:faraujo@cefet-ri.br

${ }^{2}$ Associate Professor. Industrial Engineering Department PUC-Rio - Pontifical Catholic University of Rio de Janeiro, Rio de Janeiro, Rio de Janeiro - Brazil.Tel: +55 21 3527-1284. Email: prtd@puc-rio.br

${ }^{3}$ Emeritus Professor. Political Science Department UFF - Federal Fluminense University Niterói, Rio de Janeiro - Brazil

Tel: +55 21 9998-1823. Email:wlongo@hotmail.com
} 


\section{Introduction}

'The shipbuilding industry revived' - impresses the cover story of the "Transperto" newspaper, in its 105 edition, distributed between November/December 2010. The enthusiastic title of the "Petrobras" subsidiary publication contrasts with the reality observed at the decks of Brazilian shipyards: scrapping of industrial installations; construction technologies of the excelled ships, in 30 years in relation to the technical state; failure of modern practices of production management; reducing the levels of qualifications of labor; very low articulation between the industry and research centers; the absence of development and innovation claims.

Associated to aforementioned factors, the reduced interaction between scientific and industrial policies so that the sector could head in the opposite direction of international benchmarks, which is in favor of the reduction of transaction costs and the earnings in terms of technological learning derived from homogeneous industrial areas, in addition to continuous investments, public and private, in research, development and innovation $(R \& D+I)$.

Therefore an acute contrast is observed between political discourse of the Federal Government and its companies (Transpetro e Petrobras) and the technical reality, technological and managerial of the shipbuilding industry. In this regard, and from the recognition of the central role of innovation as one of the most relevant elements for industrial competitiveness and prosperity of countries and firms (Tigre, 1997), the present study aims to diagnose the barriers to innovation in the sector and propose recommendations to constituent stakeholders of the industry oriented to sectoral strengthening.

The said diagnostic is based on the application of a methodological proposal for the analysis of sectoral systems of innovation (Araujo, 20II), which contemplates:

-The identification of the main constituent stakeholders of the Brazilian shipbuilding industry, as well as its activities or individual functions.

-The identification of the existing interrelationships between stakeholders of the said industry, de forma in order to provide a current overview related to the levels of innovation in the sector.
- Recommendations which aim at qualitative development of the intensity of interaction flow between organization and institution components of the sector, in addition to recommendations to policy makers guided to the suppression of possible gaps observed in politic policies used to shipbuilding.

In temporal terms, the study analyzes more actively the Brazilian shipbuilding industry in the period from 2005 to 2011 , scheduled for superior state investments to US\$50 billion in orders of vessels (Passos, 2007). The volume of investment draws attention, especially, when considering the liabilities (historical, technological, management, educational, among others), observed in the sector between the decades of 1980 and 1990.

It is worth highlighting that the present study represents a contribution to the study of system innovation, both under a theoretical-methodological perspective by presenting a methodology for empirical research in industries, regarding the application of the proposed method in an industrial segment, which recuperates itself after a long period of stagnation and which still lacks studies associated to innovation.

The article is organized in five sections, namely: in section two the main reasons discussed are in relation to innovation and system innovation which sustain the methodological proposal adopted in the empirical study. In the third section, a methodology used in investigation is presented. In section four a brief historical presentation was made, characteristics and particularities of the Brazilian shipbuilding industry, also described the application of the methodology for the analysis of sectoral systems of innovation, with evidence and discussion of the research results. Finally, the conclusions and suggestions of new studies are presented in the fifth and final section. 


\section{Literature Review \\ Evolution of development models of innovation}

Although the business value, primarily, the innovation as a result, in academic terms is also relevant to be investigated the processes which contribute to the innovation.

Literature describes that, with greater intensity since the mid 1980s, as a basis about which process of innovation was marked were altered substantially (Freeman, 1987; Dosi et alli, 1988; Lundvall, 1992). Until then, the linearity of a mature model through practice of technology producers is noticed (Figure I) the main standard to be pursued for the generation of innovations.

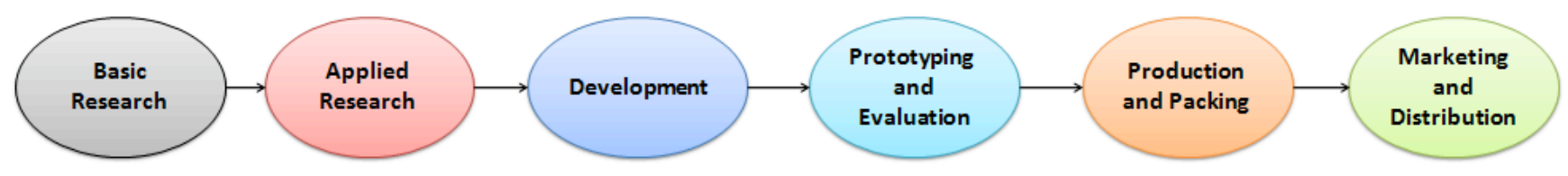

Figure I. Stages of technological innovation under the perspective of producers. Data based on NSF (1983).

The above standard refers to Linear Model of innovation, first described in the report "Science, the endless frontier", elaborated by Vanevar Bush (1945). The simplicity of this approach contributed to rapid popularization between developers of public politics, establishing to the time a new paradigm of scientific politics and technology, adopted by the majority of industrialized countries as the dominant standard of generation and diffusion of innovations, until the 1980s.

The limitations shown through the Linear Model (as: the excessive support on scientific research as an inspiration of new technologies, in addition to the sequential and "technocratic" approach of the process) reinforced the emergency for the appearance of non linear or interactive approaches, able to contemplate the numerous relationships between science, technology and the innovation process, in all the phases. Moreover, the necessity of comprehension and formulation of national politics related to the innovation impose the creation of new or adjustment of models, which better reflect the reality realidade (Sirilli, 1998; Conde and Araújo-Jorge, 2003).
Thus, from the mid 1980s, with a great influence of studies of Kline and Rosemberg (1986), the Linear Model was severely criticized, having developed approaches, which are said to be more interactive for phenomenological comprehension.

Among the interactive perspectives, The System of Innovation approach stands out by seeking to understand the role of each stakeholder, individually and in relation to the others, for the innovation (Freeman, 1982, 1987; Kline, 1985; Dosi et alli, 1988; Lundvall, 1992; Edquist, 1997, 2001; Cassiolato, Lastres and Arroio, 2005; Malerba, $1999,2002,2003,2005)$. Furthermore, it enables the segmentation of the innovation processes in distinct levels of analysis (boundaries of innovation systems), according to the researcher's interest. 


\section{Interactive Approaches: System Innovation}

According to the Oslo Manual (OECD, 2006), the channels and network communication through which information circulates, falls within a social, political and cultural basis, which simultaneously guides and restricts the activities innovative trainings. In this context, the innovation is seen as a dynamic process in which the knowledge is accumulated through the means of learning and interaction.

Edquist (200I) e Marques and Abrunhosa (2005) highlight two more relevant points about the systemic approach: the first point concerns the broad consensus between the scholars of innovation in the sense of considering the systemic approach as more complete and appropriate representation of reality; the second point presents the said approach as a useful theoretical framework to guide the policy maker.

\section{Boundaries of innovation systems}

The establishment of boundaries of innovation systems is not easy, under the practical or theoretical perspective. However, this effort is a contributory methodological approach for a more precise cutting about intrinsic elements [target system] and extrinsic [environment] to the system you wish to investigate.

Geographically, the boundaries of innovation systems can be supranational, national or sub national (regional or local) - and at the same time to be sectorals, enrolled in these geographical boundaries, having several possible combinations. In spatial terms, distinct opportunities can be observed for studies which can privilege from the most comprehensive aspect and often less accurate relating to innovation (NSI) until it gets to the more defined, specific and particular dimensions, as in the case of Local and Regional Systems of Innovation. The choice of one or another approach represents a researcher's methodology.

This present study, having in view the objective explicated in the introduction, dedicated itself to applying a specific methodology for analysis of SISs - Sectoral Innovation Systems. It is worth emphasizing that in the analyzed shipbuilding industry, the geographic/spatial focus of innovation systems loses some of its meaning, since the sector is increasingly distributed throughout the Brazilian territory.

\section{Sectoral Systems of Innovation}

The SSI approach appropriates itself to a multidimensional, integrated and dynamic vision of sectors in order to analyze the innovation. It has its origins in the concept of industry (or sector), traditionally used in the industrial economy, to the extent in which other agents should be considered in addition to firms. This approach dispenses greater emphasis on knowledge, learning and sectoral limits; it focuses the interactions of non-market interactions, just as the interactions of the market in addition to highlighting the role of institutions (Silvestre and Dalcol, 2006).

In conceptual terms according to Malerba (2002), a Sectoral System of Innovation (SSI) can be understood as:

"[...] a set of new and established products for specific uses and the set of agents carrying out market and nonmarket interactions for the creation, production and sale of those products. A sectoral system has a knowledge base, technologies, inputs and an existing, emergent and potential demand" (Malerba, 2002: 250).

According to Malerba, the main stakeholders, which make up an SSI include: Individuals (consumers, entrepreneurs, scientists); Firms (users, producers and input suppliers), non-business organizations (universities, research institutes, financial agents, trade unions and technical associations); Departments of large organizations, such as R\&D or the production department; Groups of organizations (industrial associations).

According to Malerba (2002), each of these stakeholders, individually has specific skills of processing and storage of packages of knowledge, within its institutional intrinsic context. In the author's view, different stakeholders know to create distinct activities in unique ways. Thus, the learning, knowledge and behavior are understood as rooted in the heterogeneity of these stakeholders, for their experience, competence, and organization and outstanding performance.

Finally, in Malerba's view (1999, 2002, 2003 and 2005), the concept of sectoral system of innovation can still provide a useful tool in several ways:

-For the descriptive analysis of differences and similarities in the structure, organization and boundaries of a particular sector; 
- For a complete understanding of the differences and similarities at work, dynamics and transformation of sectors;

-To identify the factors that affect innovation, business performance and competitiveness of firms and countries in different sectors and;

-To develop public policy proposals.

\section{Research Methodology}

The scarcity in literature of structured methodological procedures, dedicated to the understanding of the determinants of innovation for industrial sectors, represents a gap repeatedly highlighted in the study of leading scholars of Systems Innovation Approach (Senker et alli, 1999, Edquist, 200I; Cassiolato and Lastres, 2005).

In this case, the suppression of the theoretical and conceptual gap represents an important contribution to the development of the field of knowledge concerning the phenomenological understanding of complex technical, technological, managerial and social processes, among others, which culminates in the innovation of many different industries.

In order to reduce the said gap, Araujo (20II) presents the development of a methodology for analyzing entitled IDIVIER for the analysis of sectoral systems of innovation which would be adopted in this work. In the referred methodology, each letter represents one of the seven steps proposed to the full analysis. Additionally, the present research considers the following boundary conditions:

-Defining the object of research: the Innovation Systems Approach seeks to understand the role of each stakeholder - individually and in relation to the others - for innovation. It also enables the segmentation of the innovation processes at different levels of analysis, from geographic/ technical boundaries, according to the interests of the researcher.

In this regard, it is important to consider the individual motivations of the author to understand the evolution and current dynamics of innovation in an industrial sector with historical relevance to Brazil, whether in terms of development of national engineering, either in a high absorption of labor and promotion of productive chains.

-Sample definition: Once the Sectoral Innovation Systems are usually geographically decentralized, it is important that technical criteria associated to sampling are defined and provided to the extent in which requirements are closely related to feasibility of implementation, validation and significance of the research.

In the investigation of the Brazilian shipbuilding industry, for an appropriate parameter directed to the composition of the sample adopted the metric processing capacity of steel per year (a thousand tons per year), according data of SINAVAL (20I0), as illustrated in Table I.

\begin{tabular}{|lllcc|}
\hline$\#$ & \multicolumn{1}{c}{ Shipyard } & \multicolumn{1}{c}{$\begin{array}{c}\text { Location } \\
\text { (City, State) }\end{array}$} & $\begin{array}{c}\text { Processing/ year } \\
\text { (thousand tons/ year) }\end{array}$ & $\begin{array}{c}\text { Relative Frequency } \\
\text { Brazil }\end{array}$ \\
\hline $\mathbf{1}$ & Eisa & Rio de Janeiro, RJ & $\mathbf{5 2}$ & $\mathbf{9 . 2 5 \%}$ \\
$\mathbf{2}$ & BrasFels & Angra dos Reis, RJ & 50 & $8.90 \%$ \\
3 & Rio Nave & Niterói, RJ & 48 & $8.54 \%$ \\
4 & Enavi-Renave & Niterói, RJ & 40 & $7.12 \%$ \\
$\mathbf{5}$ & Mauá & Niterói, RJ & 36 & $\mathbf{6 . 4 1 \%}$ \\
$\mathbf{6}$ & STX Brasil & Niterói, RJ & 15 & $\mathbf{2 . 6 7 \%}$ \\
$\mathbf{7}$ & Atlântico Sul & Suape, PE & $\mathbf{1 6 0}$ & $\mathbf{2 8 . 4 7 \%}$ \\
\hline & & Total: & $\mathbf{4 0 1}$ & $\mathbf{7 1 . 3 5 \%}$ \\
\hline
\end{tabular}

Table I. Selected sample. Data based on SINAVAL (2010) 
It is important to consider as a limitation of the study, three of the seven shipyards indicated for research did not prove to be receptive, so some interviews and field visits could not be performed. Nevertheless, it is notable that in relation to the size and production capacity, two respondents are among the top three in Brazil (South Atlantic and EISA) and that together, the four shipyards surveyed (South Atlantic, EISA, Mauá and STX OSV) are responsible for processing $263 \mathrm{mil}$ tons of steel per year, equivalent to $53.91 \%$ of the entire industry.

- Techniques of data collection: for structuring an industry study it is relevant to know the trajectory of the sector historically, politically, technically, managerially and technologically. To support this understanding, a broad review of scientific and technical literature should be developed, aimed at the formation of a panel containing the main elements of the industry under study, besides the identification of central stakeholders and relationships in the sector. It is also required of the researcher an on-site contact with the reality of the industry studied. In case, the contact was aimed to provide primary data collection.

On the adopted methodology, each stage is fed by inputs (inputs) which after the specified processing generate outputs (outputs) that could support the subsequent step (Table 2). 


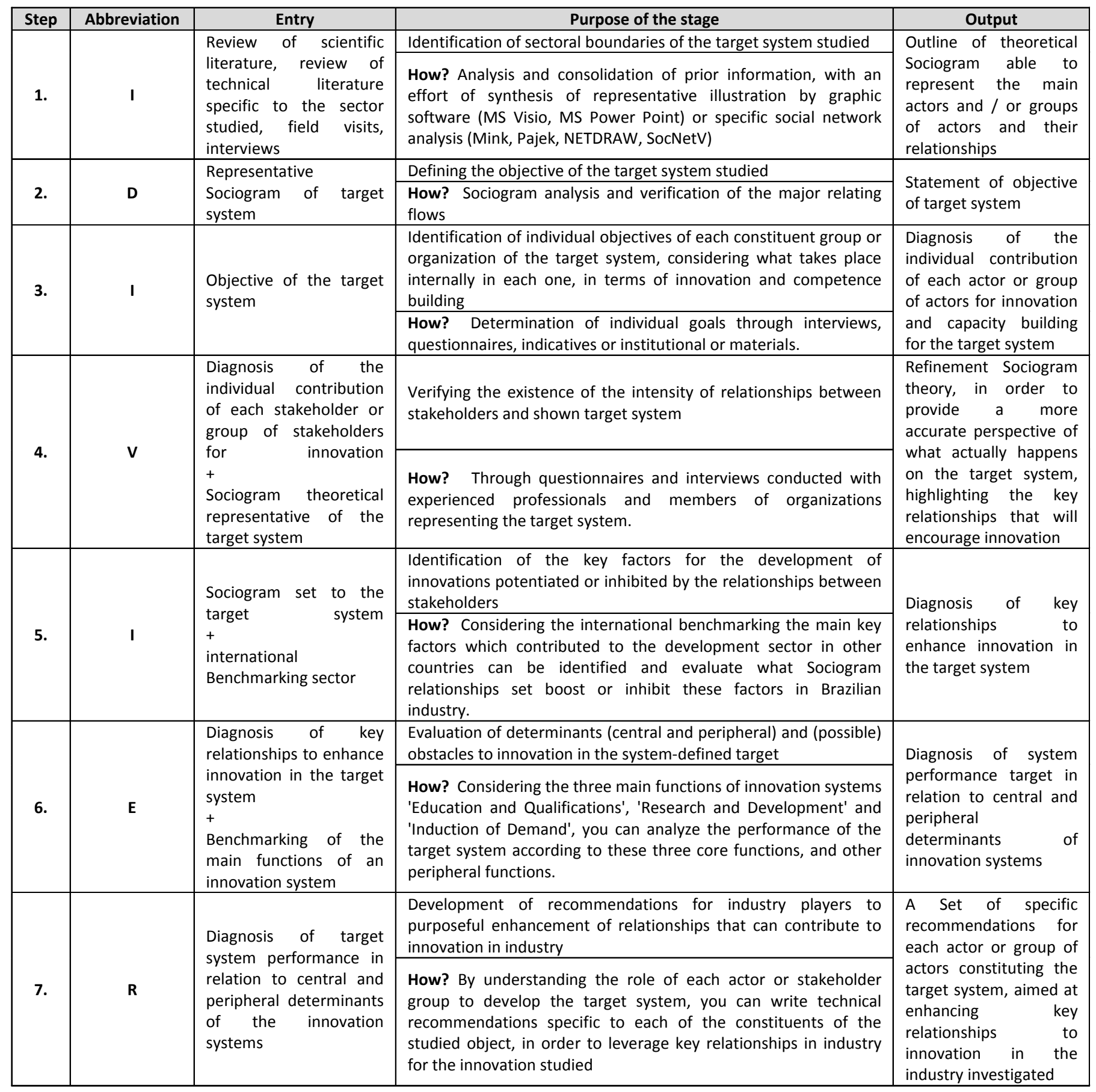

Table 2. Methodology Steps IDIVIER. Based on Araujo (20II) 


\section{Brief history of the shipbuilding industry in Brazil}

Although the origin of the Brazilian shipbuilding industry dates back to the beginning of the sixteenth century, with the production of small vessels for fishing activity, it was only on August II, 1846 that operations related to shipbuilding venture was recognized as formal venture, through the Baron of Mauá initiative to the Establishment of Foundry and Shipyard of Ponta d'Areia, located in Niterói, State of Rio de Janeiro (BNDES, 1997, Lima and Velasco, 1998; Pasin, 2002; Telles, 2004).

Between its founding and practically the closing of the activities of the quoted Establishment, in 1890, over 70 ships powered by steam and / or sailing were built to trade in the country (Estaleiro Mauá, 2009).

In Pasin's (2002) view:

"Entering the country as the agrarian economy in the international order and the interests of dominant groups, did not provide support for a representative resource mobilization required for a perennial industrialization. Therefore, after the pioneering initiative of the Baron of Mauá followed by short periods of increase of naval industrial activity, especially in the 1930s. These outbreaks, however, it was usually related to short and tight orders" (Pasin, 2002: 123).
After decades of stagnation, it is only from the second half of the twentieth century that the Brazilian shipbuilding began to receive appropriate incentives for their development. The proposed Brazilian industrialization is materialized on the Federal level, through Target Plan proposed by the government of Juscelino Kubitschek (1956-196I), which provided an accelerated economic growth from stimuli aimed at boosting the industrial sector (Junqueira, 2003; Favarin, 2008).

The Target Plan Goals for JK advocated the intense involvement of the public sector in direct and indirect stimulus to investment in infrastructure and in the industry of capital goods, with orientation to the formation of Brazilian industrial base and the substitution of importation. The plans and incentives of the Federal Government were effective and made as in the 1970s, Brazil was ranked among the largest shipbuilders in the world, with an industry employing directly about 40,000 workers, as shown in Figure 2 (Lima and Velasco, 1998; Lacerda, 2003; Junqueira, 2003).

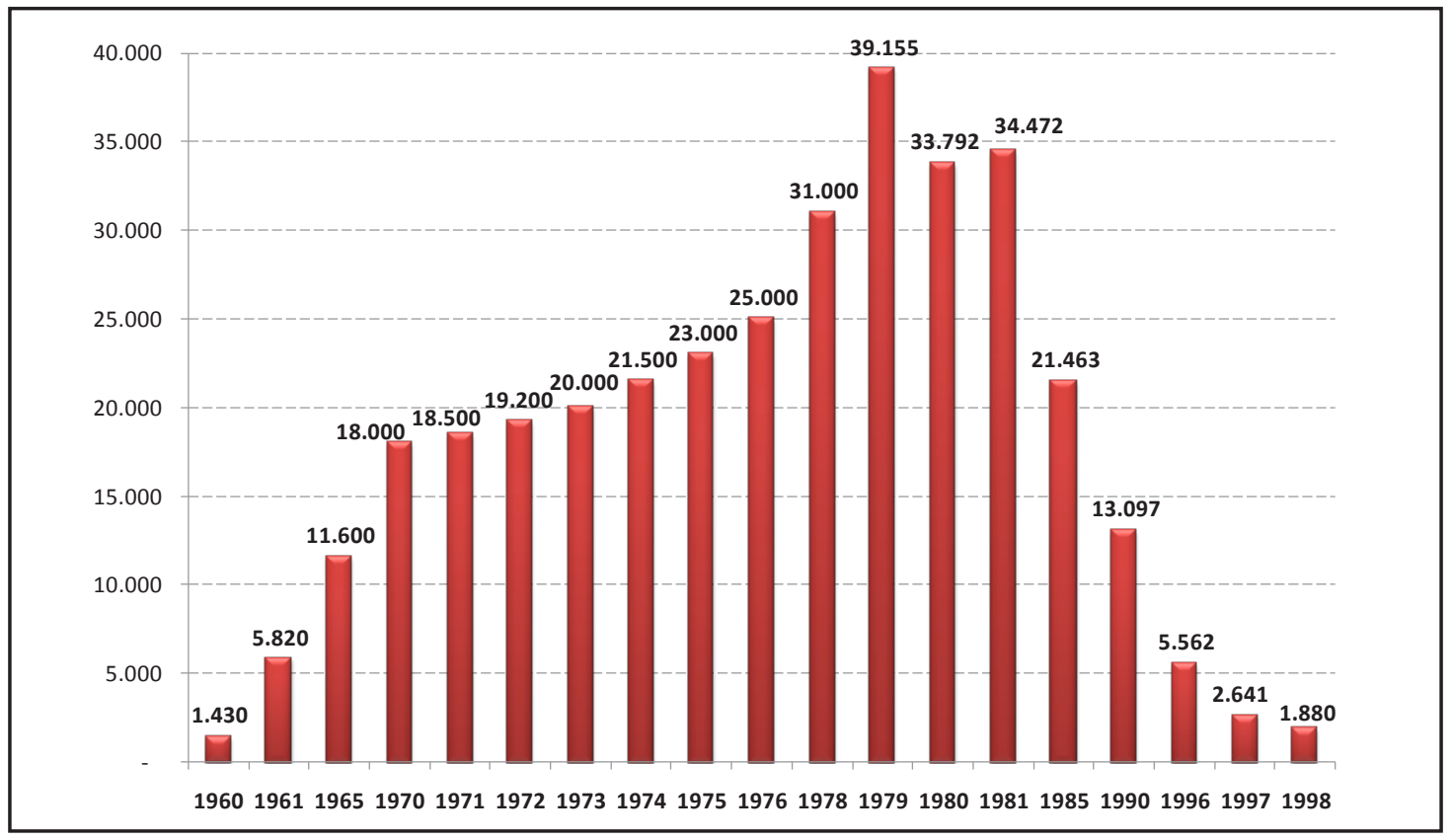

Figure 2. Labor directly employed in the shipbuilding industry between 1960 andI998. Data from Pasin (2002) 
Paradoxically, after outstanding prosperity, between the early 1980s and late 1990s, the Brazilian shipbuilding industry faced a period of drastic fall in the levels of production, which a literature associated with factors such as: the oil crisis worldwide; indiscriminate granting of allowances for a long period of time (more than 20 years), without demanding an increase in productivity that would compel the increase of competitiveness of the industry, dependence on orders from the state sector (Petrobras and Companhia Vale do Rio Doce) and; the long period of economic instability and high inflation, which affected the entire industry of capital goods under order of and particularly, shipbuilding - which requires two years, on average, for work and manages hundreds of suppliers (Lima and Velasco, 1998; Passos, 2007; Favarin, 2008).

The beginning of the revitalization of the shipbuilding industry in Brazil primarily occurred from the late 90 s, with the proclamation of Law 9,478 of 1997, known as the Petroleum Law, which made the exploration and production of Brazilian oil flexible. According to Pasin (2002), this law opened the market for the exploration and refining of hydro carbonate to new players, accelerating the expansion of offshore oil exploration. Associated to this factor, the development of new technologies for the exploitation of water depths, ultra-deepwater contract through Petrobras demanded the contraction of marine services of vessel support in the beginning of the year 2000 , which originated orders to national shipyards.

The Program for Modernization and Expansion of the Transpetro's Fleet (PROMEF), announced in 2005, provides until 2012, investments of over US $\$ 50$ billion for purchasing, in Brazil, of: 42 large vessels; 07 offloading vessels, 146 offshore support vessels and, 40 drill ships, up to 2012 (Passos, 2007). The orders of Transpetro require a level of $65 \%$ nationalization of the materials utilized, seeking the international competitiveness of suppliers, increasing its export power (Junqueira, 2007).

Regarding the resumption of efforts by the Brazilian shipbuilding industry, Paletta (2006) states that:

"This fact means a change in the industry model of large ships in Brazil, generating as a consequence of sector modernization, greater competitiveness in the international market, generating 22.000 new jobs and, especially, the reopening of a large ready market for incorporating goods and services aligned with its supply chain" (Paletta, 2006: I).

According to Passos (2007), although the incentives to revitalize the shipbuilding are relatively recent, one can already see positive results concerning this new industrial policy, such as: the reactivation and repair of the industry of shipbuilding, with financing of $\mathrm{R} \$ 4.6$ billion by the Program for Promoting the Development of Merchant Marine; reflections in the industries and basic metallurgic industries, steel makers and ship parts and gradual recovery of employment levels.

Regarding the last point it is important to stress that, according to the data of SINAVAL (20lla), the number of direct employees in the recent years (1998-2010) in the sector, is approximately $50 \%$ higher than that observed in the golden period of the Brazilian shipbuilding industry (Figure 3)

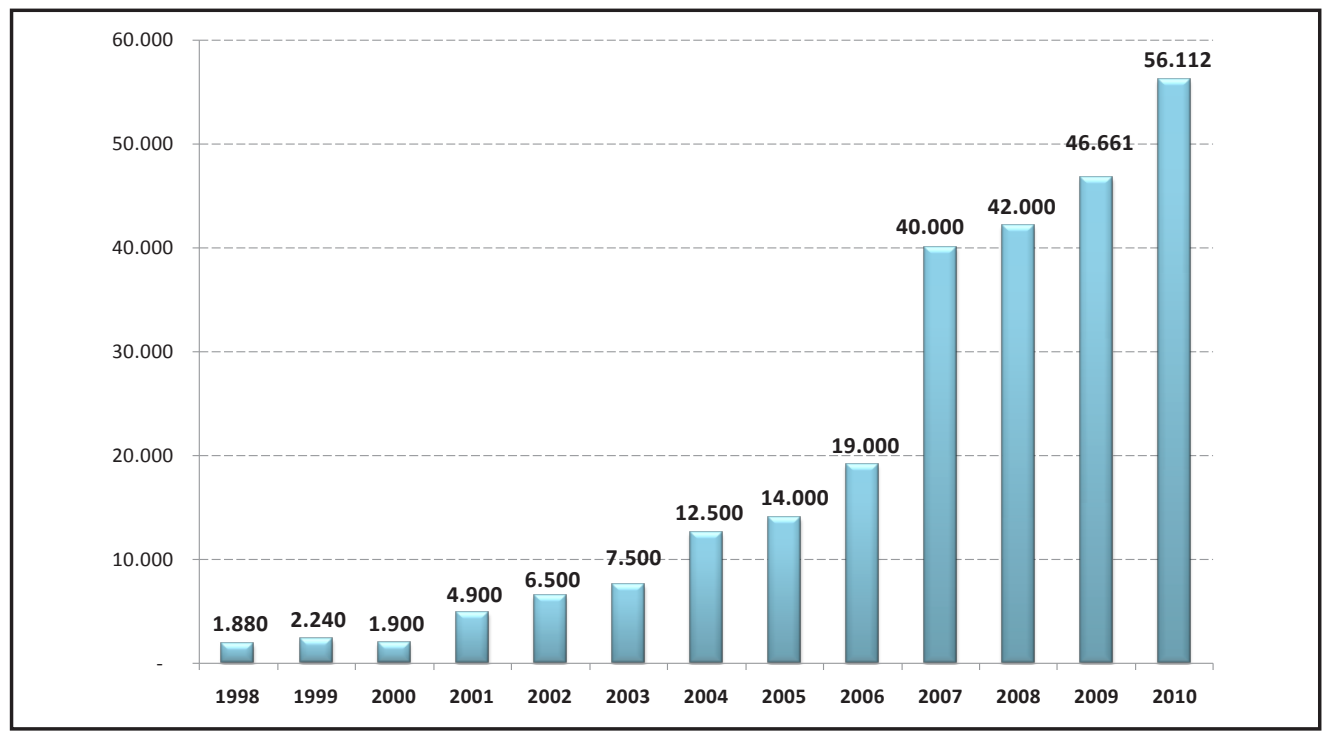

Figure 3. Labor directly employed in the shipbuilding industry between 1998 and 20I0. Data from SINAVAL (20Ila)

ISSN: 07I8-2724. (http://www.jotmi.org)

Journal of Technology Management \& Innovation ( ) Universidad Alberto Hurtado, Facultad de Economía y Negocios 
Despite the undeniable efforts, from 1997 by the Brazilian government (and their companies) to resume the course of growth of the shipping industry, through productive development policies, there are important gaps to be filled, especially concerning the systemic articulation of stakeholders and efforts aimed at the innovation of industrial competitiveness.

It is therefore relevant that the recovery process of the shipbuilding industry and new challenges in pursuit of international competitiveness is to be studied through a methodology, which is capable to understand the systemic impact, derived from shares of multiple stakeholders for the sustainability of development of the sector in vogue.

\section{The application of the IDIVIER Methodology}

To facilitate the implementation of the proposed procedures 19 interviews were carried out, taking into account different stakeholders, which together cover the group of organizations and institutions which makes up the sectoral system of innovation in the Brazilian shipbuilding industry. Each of the seven steps listed in IDIVIER methodology will be presented and treated sequentially and separately.

\section{Step 0I: identification sectoral boundaries of the target system studied}

According to what was discussed in the literature review and indicated in the methodology IDIVIER, it is possible to identify the boundaries of a system, detailing its interior (target system) in relation to the environment. That way, from an extensive review of technical literature about the Brazilian shipbuilding industry an appropriate software representation of the target system can be generated.

Figure 4 illustrates a perspective of sectoral boundaries of the Brazilian industry of shipbuilding, according to the researcher's perception, identifying the main sub systems constituents.

All subsystems will be discussed and in detail ahead. It is still valid to point out that at this time of the study. The links between groups of stakeholders are figurative, being represented merely in the sense of presenting a preliminary sketch on the researcher's perception of the object of study. The refinement and validation of the subsystems and relationships represent one of the steps of the Araujo (20II) methodology, where adjustments will be provided from empirical research.

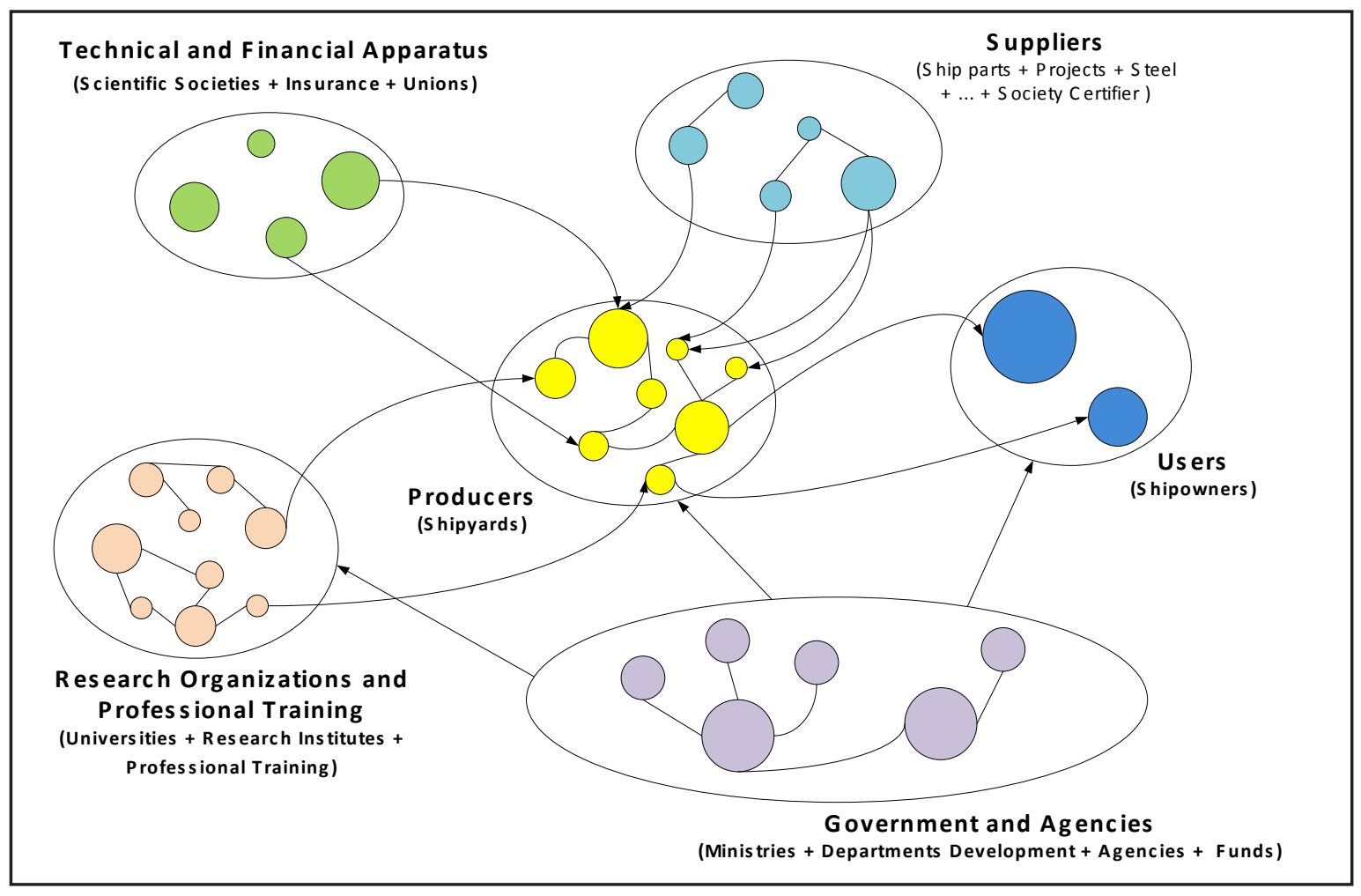

Figure 4. Theoretical representation of the sectoral boundaries of the target system studied

ISSN: 07I8-2724. (http://www.jotmi.org)

Journal of Technology Management \& Innovation (c) Universidad Alberto Hurtado, Facultad de Economía y Negocios 
As the Figure 4 illustrates a representative of the target system, the shipbuilding strict sense (subsystem Producers) refers to the set of shipyards that function under order in the manufacturing, adaptation and or repair of ships and platforms.

In the shipbuilding industry, ship owners (or fleets) are known as ship owners represented by organizations, such as, public, private or the armed forces which demand the vessels for the development of its operations of navigation, transport, marine support and or military purposes.

The following are considered suppliers of shipbuilding industry: companies engaged in the design of projects, companies engaged in the production of plates, alloy and steel profiles, suppliers of complex components such as propellers, engines, navigation equipment, hospitality furniture, marine paints and varnishes; ship parts, in general, specialized technical services, among others. A specific type of supplier and a leading role in the shipbuilding industry is known as the Society Certifier (SC).

The SCs (e.g. ABS - American Bureau of Shipping) has an important role in the construction industry, especially with concerning the safety of navigation, the crew and the environment. It is the civil society organizations in the public interest and private law, which are responsible for the approval of basic design skills during the construction, through the issue of technical reports and verification of the accordance of ship construction, the issuance of technical reports and verification of the construction of the ship, on the basis of international conventions and codes of IMO - International Maritime Organization (UN body), and the recommendations of MARPOL - Maritime Pollution and SOLAS - Safety of Life at the Seas, ratified by the Brazilian Maritime Authority.

The termed technical and financial apparatus represents a subsystem composed of organizations with different profiles and attributions. According to the proposed model, it integrates this subsystem Scientific Societies, Unions and Insurance companies (Protection and Indemnity Clubs), which act directly and / or influence the industrial dynamics.

The subsystem "Research Organizations and Professional Training" is integrated with universities, research institutes and professional training institutions to develop studies and research related to the shipbuilding industry, in addition to being trainers skilled in labor to function in the sector. In Brazil, in addition to research, the universities also operate in the training of naval engineers and highly qualified professionals, through their Masters and PhD courses, the Institute for Technological Research (IPT), a national benchmark in terms of innovation, research and development, technological service in the naval area, and, the National Service of Industrial Learning (SENAI), considered as one of the most important organizations related to the formation of skilled technical labor to function in the industry.

Last but not least, the subsystem "Government Agencies and Funds," represent the Federal Public Sector power, State and Municipal, with its ministries and departments which emerge from industrial and technological public politics, applied by their agencies, and businesses. In Brazil, directly, the Ministries of Transport (MT), Development, Industry and Commerce (MDIC) and Science and Technology (MCT), other than agencies, such as, and FINEP e BNDES, CAPES, CNPq, the National Petroleum Agency (ANP) and Inmetro, represents the main Brazilian organizations which have relevant participation in the shipbuilding sector.

\section{Step 02: definition of the objective of the target system studied}

Considering it representation of the system-target, the object of this inquiry, observe the focus on the producers (shipyards) in the flow of the chain of value of an intricate net of relationships and transactions of tangible and intangible resources, that culminate in offering maritime transport.

\section{Step 03: identification of the individual objectives of each group or constituent organization of the system-target, analyzing what occurs internally in terms of innovation and construction of abilities}

In this third stage of methodology IDIVIER, we look for evidence of individual objectives of each group (subsystem) or constituent organization for the achievement of the macro objective of the target system. In this phase, secondary as well as primary data were incorporated, proceeding from the interviews carried through. Table 3 consolidates findings proceeding from the field inquiry and the other information collected together with the investigated parties. 


\begin{tabular}{|l|l|l|}
\hline \multicolumn{1}{|c|}{ Subgroup } & \multicolumn{1}{|c|}{ Objectives related to target system } & \multicolumn{1}{c|}{$\begin{array}{c}\text { What is domestically developed in terms of } \\
\text { innovation }\end{array}$} \\
\hline Producers & $\begin{array}{l}\text { Internalize the technical, managerial and } \\
\text { technology that contribute to increased } \\
\text { productivity and reduced construction } \\
\text { costs }\end{array}$ & $\begin{array}{l}\text { Investments in industrial facilities and } \\
\text { optimizing the physical layout }\end{array}$ \\
\hline Suppliers & $\begin{array}{l}\text { Contributing yards through the } \\
\text { presentation of relevant inputs, such as } \\
\text { engineering, advances in security } \\
\text { requirements and components }\end{array}$ & $\begin{array}{l}\text { Partnerships with organizations aiming at a } \\
\text { higher qualification }\end{array}$ \\
\hline Users & $\begin{array}{l}\text { Induce demand for new vessels specifically } \\
\text { directed to the Brazilian shipbuilding } \\
\text { industry }\end{array}$ & $\begin{array}{l}\text { Using purchasing power to restructure the } \\
\text { construction industry the shipbuilding } \\
\text { industry }\end{array}$ \\
\hline $\begin{array}{l}\text { Research } \\
\text { Organizations and } \\
\text { Professional Training }\end{array}$ & $\begin{array}{l}\text { Encourage the inclusion of technological } \\
\text { innovation on the agenda of the producers. }\end{array}$ & $\begin{array}{l}\text { Development of applied research projects, } \\
\text { training of high-performance, qualification } \\
\text { of labor }\end{array}$ \\
\hline $\begin{array}{l}\text { Technical and } \\
\text { Financial Apparatus }\end{array}$ & $\begin{array}{l}\text { Pointing technical demands, technological } \\
\text { and management to competent } \\
\text { authorities. Promoting an innovation } \\
\text { network for industrial competitiveness }\end{array}$ & $\begin{array}{l}\text { Creation of mechanisms for coordination } \\
\text { between different stakeholders of the } \\
\text { Brazilian shipbuilding industry oriented } \\
\text { innovation }\end{array}$ \\
\hline $\begin{array}{l}\text { Government and } \\
\text { Agencies }\end{array}$ & $\begin{array}{l}\text { Create and implement public sector } \\
\text { development, promote the } \\
\text { competitiveness of domestic industry, } \\
\text { according to the motto: "do in Brazil, all } \\
\text { that can be done in Brazil" }\end{array}$ & $\begin{array}{l}\text { Promotes and / or contains a series of } \\
\text { political mechanisms, technical, fiscal and } \\
\text { non-fiscal, consolidated in its Production } \\
\text { Development Policy (PDP) and } \\
\text { developments specific to the shipbuilding } \\
\text { industry }\end{array}$ \\
\hline
\end{tabular}

Table 3. Summary of the goals of individual members of a target system and analysis of what happens internally in terms of innovation and skills development

Step 04: verify the existence and intensity of the relationship between stakeholders and the target system The verification of the existence and intensity of the relationship between stakeholders in the target system is made evident through the interviews conducted with experienced professionals and members of organizations representing the target system. Figure 5 summarizes the results obtained from the interviews, offering the opportunity to identify the interrelationships between the six different subsystems written in the target system, contributing to the refinement and validation of the theoretical elements presented on the occasion of the first representation of the target system. 


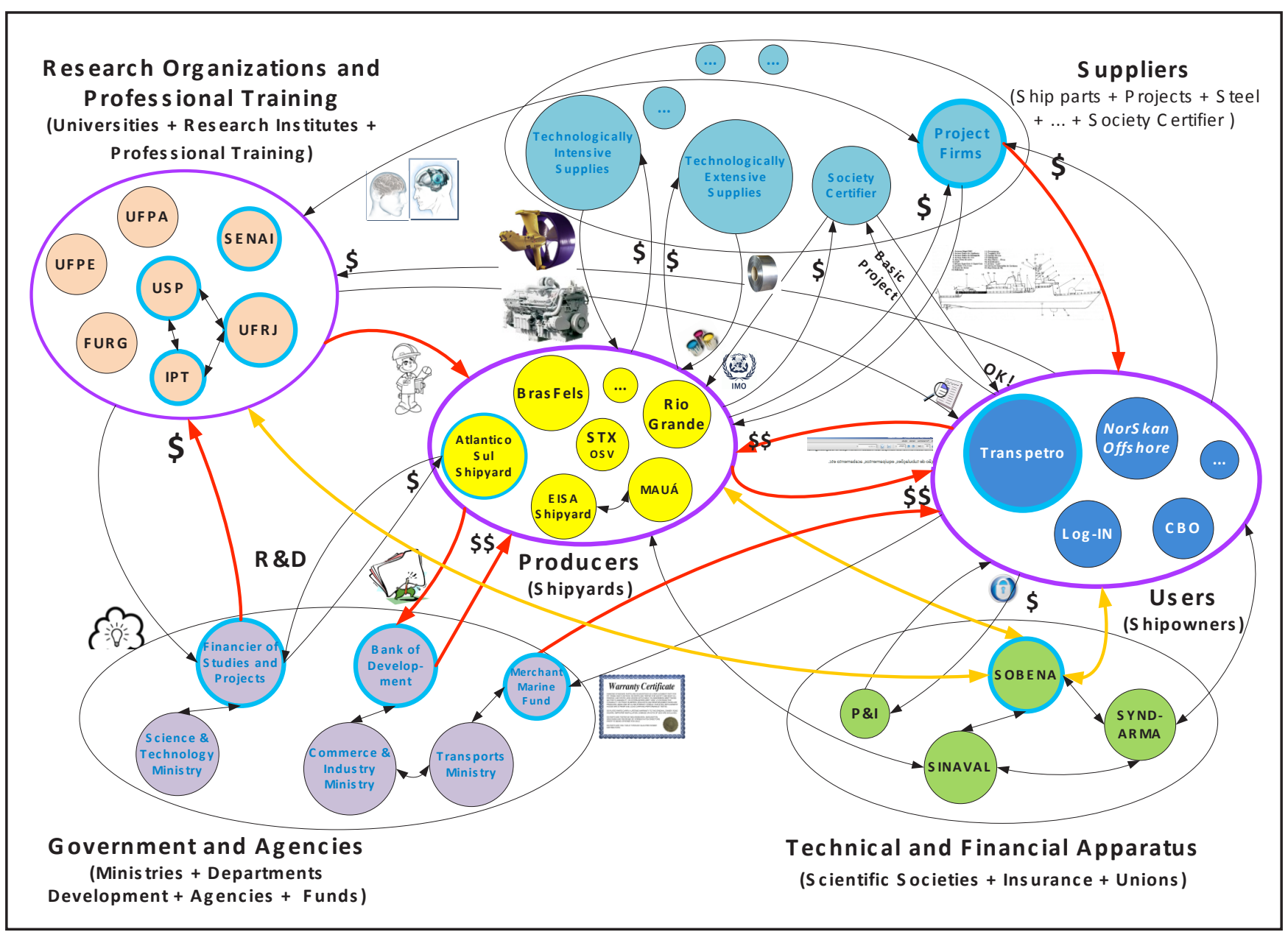

Figure 5. The representation of the Brazilian shipbuilding industry

Figure 5 was constructed based on the interviews carried through, of the immersion in the field, the revision of literature and of the technical analysis of documents, the six groups of actors (subsystems) are thereby represented, in the whole, they compose the target system of the Brazilian shipbuilding industry. The subsystems had been baptized as: "Producers"; "Users"; "Suppliers"; “Government and Agencies"; "Research and Professional Qualification Organizations", and; "Technical and Financial Apparatus".

Each one of the subsystems is composed of distinct organizations, with relevantly highlighted levels of sectoral development. For possessing particular and complementary profiles and abilities, the subsystems and the organizations integrates the target system, thus developing relationships guided to the attendance of its necessities and individual objectives. This interactive flow between organizations is perennial and necessary for the existence of the target system and, consequently, for the achievement of its objective.

\section{Stage 05: identifying key factors to develop innovations fostered or inhibited by the relationship between actors}

Recognizing that innovation is complex social process, it is observed that the Brazilian shipyard industry, even with the great investments and demands presented, moves slowly towards interaction between actors. According to what was indicated in previous discussion, it is seen that a discussed and recognized technological schedule doesn't exist, especially by the dockyards, in order to diminish its gaps regarding innovation. SOBENA, in conjunction with SYNAVAL and SINDARMA, has worked in order to bring the relevance of technological discussion and innovation to shipbuilding.

In terms of industrial structure, according to Prof. Floriano Pires Jr. (20II), the major factors of competitiveness for the sector are related to cost and manpower and the manufacture technologies - that, in his viewpoint, are 
dominated and static. In this way, the dominant standard in the shipbuilding industry in Brazil, concerning innovation, is closely related to the technological updating of the shipyards, through importing production goods and expansion and improvements in their industrial area, without explicit concern in the development of organizational policies and practices of endogenous technological domain. Contrary to the good international practices, the Brazilian shipyards, in general, do not recognize the domestic production of technology as determining factor to its competitiveness. Furthermore it is seen that this group of actors accepts the technological gap due to the fact that the contracts with riggers for building ships are signed with no objections. For the economist and advisor of the Management of BNDES, Sander Magalhães Lacerda (20I0), the current public policies related to shipbuilding refer the 1950's and do not have a clear focus on innovation. There is an evident targeting of funding to shipyards and riggers, independently, without requiring a minimal percentage of expenditure on R\&D or in innovative projects.

Table 4 summarizes the main key factors related to the innovation, fostered or inhibited by the relationships observed in the shipbuilding industry.

\begin{tabular}{|c|c|c|}
\hline Key Factors of Innovation & Relationship(s) & Result(s) \\
\hline $\begin{array}{l}\text { Direct and indirect } \\
\text { investments }\end{array}$ & $\begin{array}{l}\text { BNDES } \rightarrow \text { Shipyards } \\
\text { FMM } \rightarrow \text { Riggers }\end{array}$ & $\begin{array}{l}\text { Potentiated } \\
\text { Demand creation and contribution for modernizing scrapped } \\
\text { industrial plants and/ or foundation of new shipyards inspired in } \\
\text { Asian patterns. } \\
\text { Inhibited } \\
\text { The related public policies do not have a focus on innovation. There } \\
\text { is an evident targeting of funding to shipyards and riggers, } \\
\text { independently, without requiring a minimal percentage of } \\
\text { expenditure on R\&D or in innovative projects. }\end{array}$ \\
\hline Promotion of $R \& D+I$ & $\begin{array}{l}\text { FINEP } \rightarrow \text { Organizations of } \\
\text { Research and Professional } \\
\text { Qualification }\end{array}$ & $\begin{array}{l}\text { Inhibited } \\
\text { Technological policy implemented without observing the good } \\
\text { international practices for the sector. Descentralized investments in } \\
P \& D+1 \text { with little interaction with the specific demands of the } \\
\text { productive sector. There is no strengthening of the research } \\
\text { infrastructure nor creation of distinctive competences in remote } \\
\text { locations. }\end{array}$ \\
\hline Engineering & $\begin{array}{l}\text { Project Companies } \rightarrow \\
\text { Shipyards }\end{array}$ & $\begin{array}{l}\text { Potentiated } \\
\text { Except for specialized firms, in the Brazilian shipyards there are no } \\
\text { endogenous competences for the development of engineering } \\
\text { projects. }\end{array}$ \\
\hline $\begin{array}{l}\text { Technical or higher-level } \\
\text { manpower }\end{array}$ & \multirow[t]{2}{*}{$\begin{array}{l}\text { Research and Professional } \\
\text { Qualification Organizations } \\
\rightarrow \text { Shipyards }\end{array}$} & $\begin{array}{l}\text { Inhibited } \\
\text { Technical manpower hired to meet the demands of ordered } \\
\text { products and trained along the building process, with no experience } \\
\text { or previous qualification. High indices of rework in the shipyards. } \\
\text { Increase of demand for graduation in marine engineering. However, } \\
\text { due to the crisis of two decades, there are chronic bottlenecks } \\
\text { regarding to readiness in the capacity of provision of the new } \\
\text { demand. Retired engineers or away from the sector are "dug out" } \\
\text { or foreigners are hired. }\end{array}$ \\
\hline Production Management & & $\begin{array}{l}\text { Inhibited } \\
\text { The production management is a critical factor of success at the } \\
\text { international level. In Brazil, the practices, technologies and } \\
\text { management systems lag behind, without the necessary emphasis } \\
\text { on the production process, industrial automation and improvement } \\
\text { of manufacturing technologies. }\end{array}$ \\
\hline $\begin{array}{l}\text { Promotion of sector } \\
\text { articulation }\end{array}$ & $\begin{aligned} & \boldsymbol{\pi} \text { Riggers } \\
\text { SOBENA } & \rightarrow \text { Shipyards } \\
& \boldsymbol{y} \text { Universities }\end{aligned}$ & $\begin{array}{l}\text { Potentiated } \\
\text { Main technical and political forum in the sector; has worked for the } \\
\text { constitution of RICINO - Innovation Network for the } \\
\text { Competitiveness the Shipbuilding Industry and Offshore, initiated in } \\
\text { November } 2010 \text {. }\end{array}$ \\
\hline
\end{tabular}

Table 4. Identification of the key factors for developing innovations 
Stage 06: evaluation of the determiners (central and peripheral ones) and the (possible) hindrances to innovation in the defined target system

From the analyses made in the previous stages of the IDIVIER methodology, it is possible, in this stage, to evaluate the determining factors to the improvement of the target system, in terms of innovation. In this way, according to what Johnson (200I) suggests, it will be identified how well the functions were successfully performed by the constituent beings of the system studied.

It is appropriate, therefore, to resume, at the light of literature, which would be the expected functions to be performed by an innovation system. Table 5 provides a comparison between the perspectives of different actors in relation to the functions (synthesized in the last column) essential in an innovation system.

\begin{tabular}{|c|c|c|c|c|}
\hline Rickne (2000) & $\begin{array}{c}\text { Johnson \& Jacobsson } \\
\text { (2001) }\end{array}$ & Liu \& White (2001) & Edquist (2005) & Functions \\
\hline Create human capital & Create new knowledge & Education & Competence building & $\begin{array}{l}\text { Education and } \\
\text { Qualification }\end{array}$ \\
\hline $\begin{array}{l}\text { Create and d e diffuse } \\
\text { technological } \\
\text { opportunities }\end{array}$ & $\begin{array}{l}\text { Guide the direction of } \\
\text { the research process }\end{array}$ & $R \& D$ & $R \& D$ & $\begin{array}{l}\text { Research and } \\
\text { Development }\end{array}$ \\
\hline $\begin{array}{l}\text { Create markets and } \\
\text { diffuse market } \\
\text { knowledge }\end{array}$ & $\begin{array}{l}\text { Facilitate market } \\
\text { formation }\end{array}$ & $\begin{array}{l}\text { Final use (consumers of } \\
\text { the products outputs of } \\
\text { the processes) }\end{array}$ & $\begin{array}{l}\text { Articulation of users' } \\
\text { demand }\end{array}$ & Demand Induction \\
\hline $\begin{array}{l}\text { Create and diffuse } \\
\text { products }\end{array}$ & - & Manufacturing & $\begin{array}{l}\text { Formation of new } \\
\text { producing markets }\end{array}$ & $\begin{array}{l}\text { Production and } \\
\text { Distribution }\end{array}$ \\
\hline Facilitate the funding & $\begin{array}{c}\text { Provide resources } \\
\text { (capital, competences or } \\
\text { other resources) }\end{array}$ & - & Funding to innovation & Funding \\
\hline $\begin{array}{l}\text { Facilitate the regulation } \\
\text { for technologies, } \\
\text { materials and products } \\
\text { that can widen the } \\
\text { market and/or develop } \\
\text { access to the market }\end{array}$ & $\begin{array}{l}\text { Facilitate the creation of } \\
\text { positive externalities }\end{array}$ & - & $\begin{array}{l}\text { Creation and change of } \\
\text { institutions }\end{array}$ & $\begin{array}{l}\text { Policies and } \\
\text { Regulation }\end{array}$ \\
\hline $\begin{array}{l}\text { Develop relationship } \\
\text { networks }\end{array}$ & - & $\begin{array}{l}\text { Relationship } \\
\text { (agglutination of } \\
\text { complimentary } \\
\text { competence) }\end{array}$ & $\begin{array}{l}\text { Networks around } \\
\text { knowledge }\end{array}$ & $\begin{array}{l}\text { Articulation and } \\
\text { relationships }\end{array}$ \\
\hline $\begin{array}{l}\text { Incubate (provide } \\
\text { facilities, equipment } \\
\text { and administrative } \\
\text { support) }\end{array}$ & - & - & Incubation of activities & $\begin{array}{l}\text { Support to the } \\
\text { activities }\end{array}$ \\
\hline $\begin{array}{l}\text { Manage partners' } \\
\text { technology, market and } \\
\text { research }\end{array}$ & - & - & $\begin{array}{l}\text { Creation and change of } \\
\text { organizations }\end{array}$ & \multirow{3}{*}{ Basics } \\
\hline $\begin{array}{l}\text { Legitimate technologies } \\
\text { and firms }\end{array}$ & - & - & Consulting services & \\
\hline $\begin{array}{l}\text { Create a work market } \\
\text { that can be used by the } \\
\text { NFBT }\end{array}$ & - & - & & \\
\hline
\end{tabular}

Table 5. Comparative analysis between different perspectives of the literature related to the functions of an innovation system 
When analyzing Table 5, it is seen that among the studied authors is a unanimous perception regarding the relevance of three functions for the good performance of the innovation systems, namely:

\section{i. Education and Qualification \\ ii. Research and Development \\ iii. Demand Induction}

Considering the functions $\mathrm{i}$ and ii; the industry studied, and; the IDIVIER methodology it is seen that the subsystem "Research and Professional Qualification Organizations"which encompasses universities, research centers and organizations directed to technical manpower formation - shows central relevance in the innovation process for the sector. This consideration is corroborated by the results of the empirical investigation, which point as decisive the issue of R\&D and the manpower formation in the Brazilian shipbuilding industry. It is appropriate to consider, however, that despite their relevance, there are improvement opportunities in both functions.

In spite of the great exaltation to resuming shipbuilding in Brazil, it is important to consider that, in terms of industrial productiveness, the shipyards are still moving towards incorporating both hard and soft technologies.

In hard terms (the manufacturing techniques themselves), a considerable delay of the producers is seen in relation to the modernization of their facilities and production goods. As for the soft technologies (planning techniques, organization and control of processes), the production management is usually done intuitively, with a reduced presence of specialized engineers, no incorporation of planning systems and production control, stock management and sequencing of intermediate products line, summed up to the capacity to develop own projects.

\section{Stage 07: indication of recommendation to the sector actors to potentiate the relationship able to contribute for innovation in the industry}

The seventh and last stage of the IDIVIER methodology features a set of recommendations for the actors (or groups of actors) integrating the target-systems, with the purpose of fostering virtuous relationships for innovation in the sector. The recommendations are consolidated in Table 6.

\begin{tabular}{|c|c|}
\hline Relationship & Recommendations for the Parties \\
\hline $\begin{array}{l}\text { Government/ Agencies/ FINAME } \rightarrow \\
\text { Producers }\end{array}$ & $\begin{array}{l}\text { Government/ Agencies/ FINAME: add, as new criteria for granting funding to shipyards, } \\
\text { requirements related to the endogenous development of Technologies, via R\&D, contracts of } \\
\text { transference of technology or technological partnerships with developers abroad. } \\
\text { Producers: revise their organizational culture aiming at seizing the credit opportunities and } \\
\text { governmental incentives in order to get a technological advancement able to contribute for their } \\
\text { competitiveness, at the international level, and reduce their dependences on the domestic orders. }\end{array}$ \\
\hline Government/ Agencies/ FMM $\rightarrow$ Users & $\begin{array}{l}\text { Government/ Agencies/ FMM: require minimal percentages of investment for the development of } \\
\text { innovative projects, based on R\&D. } \\
\text { Users: assess their long term demands (such as: maintenance, repair and/or ship adaptation) and } \\
\text { the future technological challenges for improvement and development of new shipbuilding projects. }\end{array}$ \\
\hline $\begin{array}{l}\text { Government/ Agencies/The Sector } \\
\text { Funds } \rightarrow \text { Research and Professional } \\
\text { Qualification Organizations }\end{array}$ & $\begin{array}{l}\text { Government/ Agencies/ Sector Funds: revise their practices related to issuing edicts for } \\
\text { spontaneous demand and spraying research resources. } \\
\text { Research and Professional Qualification Organizations: strengthen relationships with the } \\
\text { productive sector, identifying their specific demands for a better management of applied research. }\end{array}$ \\
\hline Users $\rightarrow$ Producers & $\begin{array}{l}\text { Users: assess their long term demands (such as: maintenance, repair and/or ship adaptation) and } \\
\text { the future technological challenges for improvement and development of new shipbuilding projects. } \\
\text { Producers: revise their organizational culture aiming at seizing the credit opportunities and } \\
\text { governmental incentives in order to get a technological advancement able to contribute for their } \\
\text { competitiveness, at the international level, and reduce their dependences on the domestic orders. }\end{array}$ \\
\hline $\begin{array}{l}\text { Producers } \rightarrow \text { Research and Professional } \\
\text { Qualification Organizations }\end{array}$ & $\begin{array}{l}\text { Producers: offer more initiatives to seek support of the university to solve their particular problems. } \\
\text { Research and Professional Qualification Organizations: offer specialized technical services and/or } \\
\text { proposals for applied researches able to contribute for developing the practices and the technology } \\
\text { in the shipyards. }\end{array}$ \\
\hline
\end{tabular}

Table 6. Recommendations to the sector actors to potentiate the relationships able to contribute for innovation in the industry 


\section{Conclusions and suggestions for future studies}

After applying the IDIVIER Methodology (Araujo, 20II), the analysis of the Brazilian shipbuilding industry corroborates the initial considerations, indicating that in spite of the boastful speech of the Federal Government, the Brazilian shipbuilding industry still cannot be understood as a sectoral innovation system. Concerning this, it is also seen that Brazil still has a lot to advance in sense to structuring its industrial policy that lacks focus on innovation, as well alignment with the scientific and technological policy. Besides, it's recommend to incentivizing the engagement of public and private organizations in the search for innovation.

Once it is the seventh economy in the world, with perspectives that, in the next decade be the fourth, Brazil needs, urgently, to assume the unrestricted commitment with the endogenous generation of knowledge and technologies able to contribute to leverage the country in economical and technological terms, keeping the advancements in the social field.

The public investments in research and development demand to be reviewed, because they must be aligned to the real needs of the country and the productive sector. About the funding of goods and equipments, the mechanisms should be explicit requirements regarding for the competitiveness and good management.

Specifically in relation to the analyzed sector, it is seen that the main vector of competitive orientation, at international level, is assented on innovation. The major and most productive shipyards in the world such as the South Korean Daewoo, Samsung and Hyundai, own private institute of $R \& D+\mid$ that have investment of $I \%$ of the gross sales.

On the other hand the discussion about innovation in the Brazilian shipbuilding industry is still timid both in technological terms and concerning techniques and methods of production management. It is noteworthy that, only one Brazilian shipyard had shown FINEP an implementation project of an institute of research, development and innovation.

It is important to highlight that although the innovation is a relevant issue in the shipyards rage, the technology currently used, globally, is reasonably static and the movements of the national shipyards are done towards pursuing the dominant (Asian) standard.
In addition to innovation in the shipyards, it should be considered that there are a lot of opportunities for development of innovations to the amount of the chain, towards suppliers of components and systems for ships. International data from these suppliers, of different natures, show that investments in innovation are of 6 to $8 \%$ of its revenues. This finding is relevant to be able, in Brazil, to predict the development of mechanisms for the induction of new suppliers, with the contribution of intelligence and national content, to meet the domestic and foreign markets.

Finally, another point worth mentioning concerns the question about the supply of engineering services to the Brazilian shipyards. Most of the Brazilian shipyards have no engineering department, supplying its needs through projects firms. In this respect we should also consider the importance of strengthening national engineering, either through the development of an engineering department, either through independent advice.

Of all kinds, the make-buy decisions are typical in the industrial scope and should be considered with the intention of cost rationalization, reduction of managerial complexity, and assigning greater focus on core activities. For shipyard with low processing capability, the preferred option should be the outsourcing of engineering projects. As for the large Brazilian shipyards, limit your activity, so the building of steel structures and aggregation of components and finished systems, not stimulating the engineering itself runs counter to international competitive standards.

The authors wish to carry out comparative research, periodic monitoring for the evolution of the target system in terms of innovation, in order to update the recommendations for the actors involved in industrial dynamics. 


\section{References}

ARAUJO, F.O. (20II). Proposta metodológica para análise de sistemas setoriais de inovação: aplicação na indústria brasileira de construção naval. Thesis (Doctorate in Production Engineering). Rio de Janeiro, PUC-Rio.

BNDES-Banco Nacional De Desenvolvimento Econômico E Social (1997). Construção Naval no Brasil e no Mundo. Informe Infra-Estrutura. Área de Projetos de InfraEstrutura. n.14, set.

BUSH, V. (1945). Science, the endless frontier. A report to the president by Vannevar Bush, director of the office of Scientific Research and Development. Government Printing Office, Washington, July.

CASSIOLATO, J.E.; Lastres, H.M.M. and Arroio, A.C.M. (Orgs.) (2005). Conhecimento, sistemas de inovação e desenvolvimento. Rio de Janeiro, Ed. UFRJ/ Contraponto.

CASSIOLATO, J. E. and LASTRES, H. M. M. Sistemas de inovação e desenvolvimento: as implicações de política. São Paulo em Perspectiva, v. 19, n.I, p.34-45, jan/mar, 2005.

CONDE, M. V. F. and Araújo-Jorge, T. C. (2003). Modelos e concepções de inovação: a transição de paradigmas, a reforma da C\&T brasileira e as concepções de gestores de uma instituição pública de pesquisa em saúde. Ciência \& Saúde Coletiva, 8(3): 727-74I.

DOSI, G.; Freeman, C.; Nelson, R.; Silverberg, G. and Soete, L. (eds.). (1988). Technical Change and Economic Theory. London, Pinter Publishers.

EDQUIST, C. (ed.) (1997). Systems of Innovation: Technologies, Institutions and Organizations. London, Pinter/Cassell.

EDQUIST, C. (200I). The Systems of Innovation Approach and Innovation Policy: An account of the state of the art. Proceedings of the DRUID Conference, Aalborg, June I2-I5.

EDQUIST, C. (2005) Systems of Innovation: Perspectives and Challenges. In FAGERBERG, J., Mowery, D. and Nelson, R.R. (eds.). The Oxford Handbook of Innovation. Norfolk, Oxford University Press.
ESTALEIRO MAUÁ (2009). Histórico. Disponível em http://www.estaleiroMauá.ind.br/modules.php?name=Con tent\&pa=showpage\&pid=44. [Accessed July 17, 2009].

FAVARIN, J. (2008). Estratégia para a navipeças brasileira: uma abordagem por competências. Centro de Estudos em Gestão Naval da Escola Politécnica da USP. São Paulo, USP.

FREEMAN, C. (1992). The economics of industrial innovation. Londres, Frances Pinter.

FREEMAN, C. (1987). Technology policy and economic performance: lessons from Japan. Londres, Pinter Publisher.

JOHNSON, A. and Jacobsson, S. (200I). The Emergence of a Growth Industry: A Comparative Analysis of the German, Dutch and Swedish Wind Turbine Industries. Mimeo. Department of Industrial Dynamics Göteborg, Chalmers University of Technology.

JUNQUEIRA, A. C. (2003). Contribuição para o Aperfeiçoamento de uma Política para a Indústria Naval e a Marinha Mercante. Apresentação no BNDES. Rio de Janeiro, SOBENA.

KLINE, S.J. (1985). Innovation is not a linear process. Research Management, Vol. 28, No. 2, p. 36-45, July-August.

KLINE, S.J. and Rosenberg, N. (1986). An Overview of Innovation. In LANDAU, R. and Rosenberg, N. (eds.). The Positive Sum Strategy. Washington/DC, Elsevier.

LACERDA, S. M. (2003). Oportunidades e Desafios da Construção Naval. Revista do BNDES, Rio de Janeiro, v. 10, n. 20, p. 4l-78, dez.

LACERDA, S. M. (2010). Interview with the economist Sander Magalhães Lacerda. Rio de Janeiro, BNDES.

LIMA, E. T. and Velasco, L. (1998). Construção Naval no Brasil: Existem Perspectivas? Revista do BNDES, Rio de Janeiro, v. 5, n. 10, p. 167-194, dez.

LIU, X.; White, S. (200I). Comparing innovation systems: a framework and application to China's transitional context. Research Policy, v. 30, pp. 1091-III4. 
LUNDVALL, B.Å. (Ed.). (1992). National innovation system: towards a theory of innovation and interactive learning. Londres, Pinter Publishers.

MALERBA, F. (1999). Sectoral systems of innovation and production. Proceeding of the DRUID Conference on: National Innovation Systems, Industrial Dynamics and Innovation Policy, Rebild, June 9-12.

MALERBA, F. (2002). Sectoral systems of innovation and production. Research Policy, v. 3I, pp. 247-264.

MALERBA, F. (2003). Sectoral Systems and Innovation and Technology Policy. FINEP, Revista Brasileira de Inovação, v.2, n. 2, Julho / Dezembro.

MALERBA, F. (2005). Sectoral systems of innovation: a framework for linking innovation to the knowledge base, structure and dynamics of sectors. Econ. Innov. New Techn., Vol. I4(I-2), January-March, Pp. 63-82.

MARQUES, A. and Abrunhosa, A. (2005). Do modelo linear de inovação à abordagem sistémica: aspectos teóricos e de política econômica. Documento de trabalho/ discussion paper (June) $n^{\circ}$. 33. Centro de Estudos da União Européia (CEUNEUROP). Coimbra, Portugal, Faculdade de Economia da Universidade de Coimbra.

NSF - National Science Foundation (1983). The process of technological innovation: reviewing the literature. Productivity improvement research section. Division of industrial science and technological innovation. USA, NSF.

OECD - Organization For Economic Co-Operation And Development. (2006) Manual de Oslo: diretrizes para coleta e interpretação de dados sobre inovação. 3 ed. Rio de Janeiro, FINEP/ OECD.

PALETTA, J. Revitalização da indústria naval inaugura período de oportunidades. Revista Negócios Offshore, Pp. I-9, 20 nov, 2006.

PASIN, J. A. B. (2002). Indústria Naval do Brasil: Panorama, Desafios e Perspectivas. Revista do BNDES, Rio de Janeiro, v. 9, n. 18, p. 121-148, dez.

PASSOS, P. S. O. (2007). Visão Atual e Perspectivas do Programa de Expansão e Modernização da Marinha Mercante. Niterói/RJ, FENASHORE.
PIRES JUNIOR, F. C. M. (2010) Construção Naval Potencial e Desafios da Sustentabilidade. Rio de Janeiro, Navalshore.

PIRES JUNIOR, F. C. M. (20II). Interview with the Prof. Floriano Carlos Martins Pires Junior (Vice-President of SOBENA - Brazilian Society of Naval Engineering and Doctorate Professores of UFRJ - Federal University of Rio de Janeiro). Rio de Janeiro, SOBENA, UFRJ.

QUEIROZ, A. A. F. S. L. (2009). Projeto de rede de suprimentos: um modelo colaborativo para estruturação da rede de navipeças na Indústria de Construção Naval do Brasil. Thesis (Doctorate in Naval Engineering). São Paulo: POLI/ USP.

RICKNE, A. (2000). New Technology-Based Firms and Industrial Dynamics: Evidence from the Technological Systems ofBiomaterialsinSweden, Ohioand Massachusetts. Department of Industrial Dynamics. Gothenburg/ Sweden, Chalmers University of Technology.

SENKER, J.; Marsili, O.; Wörner, S.; Reiss, T.; Mangematin, V.; Enzing, C. and Kern; S. (1999). Literature review for European biotechnology innovation systems (EBIS). University of Sussex, SPRU.

SINAVAL-Sindicato Nacional Da Indústria Da Construção E Reparação Naval E Offshore. (2010). Política industrial na construção naval: resultados positivos para a indústria de construção naval da PDP. Rio de Janeiro, SINAVAL.

SINAVAL-Sindicato Nacional Da Indústria Da Construção E Reparação Naval E Offshore (201I). Indústria da construção naval e o desenvolvimento brasileiro - 2010 . Rio de Janeiro: SINAVAL.

SILVESTRE, B. S. and Dalcol, P. R. T. (2006). As abordagens de clusters e de sistemas de inovação: modelo híbrido de análise de aglomerações industriais tecnologicamente dinâmicas. Universidade Tecnológica Federal do Paraná (UTFPR). Revista Gestão Industrial. v. 02, n. 04: p. 99-III.

SIRILLI, G. (1998). Conceptualising and mensuring technological innovation. II Conference on Technology Policy and Innovation, agosto 3-5, Lisboa.

STOPFORD, M (1997). Maritime Economics. Technical Report. 2 ed. London, Routledge. 
TELLES, P. C. S. (2004). A construção naval no Brasil. Rio de Janeiro, Fundação Cultural Monitor Mercantil.

TIGRE, P.B. (1997). Paradigmas Tecnológicos. Estudos em Comércio Exterior, v, I n, 2 - jan/jun/1997, Rio de Janeiro.

TIGRE, P. B. (2006). Gestão da Inovação: a Economia da Tecnologia no Brasil. Rio de Janeiro, Campus/ Elsevier.

TRANSPETRO (2010). A indústria naval renasceu. In: Jornal da Transpetro, v.9, n. 105, nov/ dez. 
J. Technol. Manag. Innov. 20II,Volume 6, Issue 4 